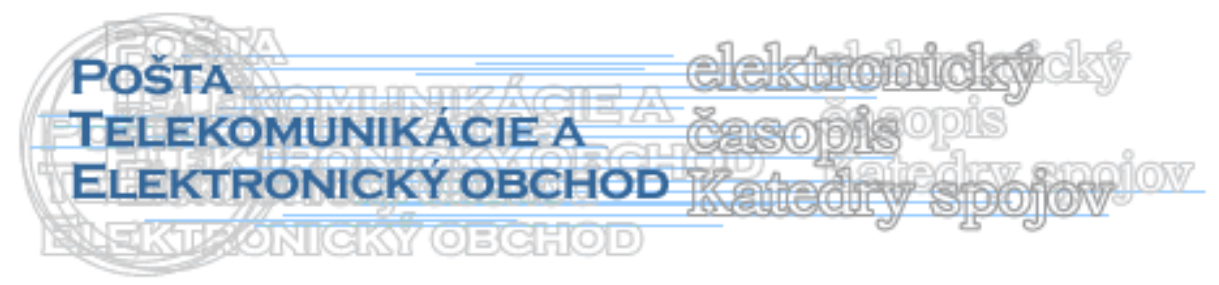

\title{
ŠTATISTIKA SPOLOČENSKEJ (VEREJNEJ) MIENKY
}

\section{Ol'ga Zajasenská*}

Spoločenská mienka predstavuje jeden z významných prameňov informácií pre prijatie primeraných praktických rozhodnutí.

V posledných rokoch sa významne rozšírilo skúmanie spoločenskej (verejnej) mienky. Ak sa pred časom názory spoločnosti zist'ovali prevažne v súvislosti s dôležitými politickými udalost’ami, celoštátnymi opatreniami, tak v súčasnosti vzrástol záujem o všetky aspekty života a činnost' spoločnosti bez výnimky.

Spoznávanie spoločenskej (verejnej) mienky má základ v špeciálnej forme štatistického zist'ovania, známeho pod názvom ,anketa“.

V značnej miere sa táto špeciálna forma zistovania používa vedeckou obcou, výskumnými ústavmi, a to za účelom zist'ovania miery pokrytia dopytu po tovare, zist'ovania mienky na kvalitu, sortimentnú skladbu tovaru v predajnej sieti a pod. Často je využívaná aj študentskou obcou pri riešení záverečných písomných prác.

Popri kladnom hodnotení efektívnosti takéhoto spôsobu zist'ovania treba upozornit' na úskalia vedecko - metodologického prístupu k skúmaniu verejnej mienky.

Štatistika spoločenskej mienky, ako súčast' ekonomickej štatistiky, má byt' chápaná ako súbor údajov, získaných z prieskumu verejnej mienky, aj ako etapy organizácie štatistického skúmania, ale aj ako metodologický postup spracovania odpovedí na otázky.

Pri použití ankety, ako formy štatistického zist'ovania, má byt' venovaná zvláštna pozornost' zloženiu anketovaných, ohodnoteniu reprezentatívnosti výsledkov z dopytovania. Vel'mi dôležité je spoznanie metodiky analýzy výsledkov, pretože tieto sú zovšeobecnením mienky osôb, ktoré majú rôzny status (vzdelanostný, profesionálny a pod.).

Zložitost' teoretických základov skúmania verejnej mienky vyplýva predovšetkým z toho, že pri skúmaní prevažujú atributívne (slovné, kvalitatívne) znaky. Tradičné štatistické metódy nie celkom splňajú úlohy, ktoré kladie analýza kvalitatívnych znakov.

Pre spracovaní získaných údajov s prevahou atributívnych znakov treba venovat' zvýšenú pozornost' štrukturálnym rozdielom, využitiu neparametrických metód testovania štatistických hypotéz, charakteristikám tesnosti vzt’ahu.

Vel'mi závažným problémom je vytypovanie a zoradenie otázok, vierohodnost' získaných údajov, apriórne riešenia rozsahu výberu, štylizácia anketného lístka.

Zatial' čo posledný z uvedených problémov sa rieši určením zatvorených, otvorených, polootvorených otázok, určenie rozsahu výberu, stupňa vierohodnosti a vypovedacej schopnosti údajov a výsledkov je zložitejšie.

Kritériá tvorby náhodného (pravdepodobnostného) výberu pre prieskum verejnej mienky sú t’ažko použitel'né, a to z dôvodu:

- rôznorodosti skúmaných vlastností,

\footnotetext{
* doc. Ing. Ol'ga Zajasenská, Csc. Katedra spojov, Fakulta prevádzky a ekonomiky dopravy a spojov, Žilinská univerzita v Žiline, Univerzitná 1, 01026 Žilina, Slovenská republika, tel.: +421415133111 , fax: +421415655615
} 
- relatívnosti kvantitatívneho vyjadrenia skúmaných objektov.

To neumožňuje odmerat' a kvantifikovat' variabilitu skúmaných znakov, na čom sa zakladá určenie rozsahu výberu.

Ako možné sa javí uplatnenie zámerného výberu, konkrétne kvótneho výberu. Podstata spočíva $\mathrm{v}$ tom, aby v mase, ktorá bude podrobená dopytovaniu (pôjde o kombináciu výberových metód), boli zastúpené všetky triedy, sociálne skupiny, vrstvy, a to v proporciách, ktoré zodpovedajú štruktúre základného súboru.

Z uvedeného vyplýva, že pre realizáciu zámerného výberu metódou kvót treba mat' určité predbežné vedomosti o skúmanom súbore. Nie je pri tom objektívne zaručené, že vybrané jednotky dobre reprezentujú skúmaný súbor. Potvrdzuje sa, (V.Čermák: Štatistika II., SNTL 1968) že aj najskúsenejší a celkom nepredpojatí znalcovia, ktorí sú poverení tvorbou výberu, majú tendenciu odkláňat' sa od priemeru jedným alebo druhým smerom.

Druhý závažný problém zámerného výberu spočíva $\mathrm{v}$ tom, že pri odhadoch urobených na jeho základe, nemožno objektívne určit' ich presnost', t.j. vypočítat' priemernú či maximálnu možnú chybu odhadu.

Pokial' ide o rozsah výberu, tento činitel' pri zámerných výberoch neovplyvňuje vel'kost' výberovej chyby alebo vôbec, alebo len nepatrne. (V.Čermák: Štatistika II., SNTL 1968).

Vel'mi významnou je (v súvislosti s vyššie uvedeným) metodológia, ktorá by umožnila získat' objektívne, pravdepodobnostné ohodnotenie výsledkov skúmania. Tá sa môže opierat' o neparametrické metódy testovania štatistických hypotéz, ktoré nie sú podmienené platnost'ou normálneho rozdelenia početností a ich užitočnost' a výhodnost' spočíva predovšetkým v tom, že majú platnost' za vel'mi všeobecných predpokladov a umožňujú pomerne rýchlo získat' požadovanú informáciu.

Zo známych testov tohto typu možno uplatnit' napr.:

- znamienkový M - test,

- Wilcoxonov $\alpha$ - test, resp. $\beta$ - test,

- Dixonov test.

Kvantifikovanie intenzity vzt’ahu medzi skúmanými znakmi predstavuje taktiež dôležitú súčast' spracovania údajov. V tejto súvislosti prichádzajú do úvahy neparametrické koeficienty korelácií, ktoré nevyžadujú žiadne vedomosti o parametroch základného súboru a vyčísl'ujú sa pomerne jednoducho. Je to predovšetkým Spearmanov koeficient korelácie, prípadne Kendallov koeficient korelácie. 